2. Bilyayev, O. M., Mel`ny`chajko, V. Ya., Penty`lyuk, M. I. 1987. Metody`ka vy`vchennya ukrayins`koyi movy` $v$ shkoli [Methods of learning the Ukrainian language at school: a guide for teachers]. Ky`yiv. Radyans`ka shkola, 246 p.

3. Chavdarov, S. X., Masal`s`ky`j, V. I. 1962. Metody`ka vy`kladannya ukrayins`koyi movy`v serednij shkoli [Methods of teaching the Ukrainian language in high school]. Ky`yiv. Radyans`ka shkola, $228 \mathrm{p}$.

4. Olijny`k, I. S., Ivanenko, V. K., Rozhy`lo, L. P., Skory`k, O. S. 1989. Metody`ka vy`kladannya ukrayins`koyi movy` v serednij shkoli [Methods of teaching the Ukrainian language in high school]. Ky`yiv. Vy`shha shk., 439 p.

5. Doroshenko, S. I., Vashulenko, M. S., Mel`ny`chajko, V. Ya. 1992. Metody`ka vy`kladannya ukrayins`koyi movy` [Methods of teaching the Ukrainian language]. Ky`yiv. Vy`shha shk., 398 p.

6. Penty`lyuk, M. I. 2000. Metody`ka navchannya ridnoyi movy` v serednix navchal'ny`x zakladax [Methods of teaching the native language in secondary schools]. Ky yiv. Lenvit, $264 \mathrm{p}$.

7. Penty'lyuk, M. I., Karaman, S. O., Karaman, S. O., Goroshkina, S. O., Bakum, Z. P., Gajdayenko I. V. 2005. Metody`ka navchannya ukrayins`koyi movy`v serednix osvitnix zakvladax [Methods of teaching the Ukrainian language in secondary schools]. Ky`yiv. Lenvit, 400 p.

8. Suxomly`ns`ky’j, V. O. 1959. Vidpovidnist' metodiv navchannya zmistu i meti uroku [Correspondence of teaching methods to the content and purpose of the lesson]. Soviet school. N. 11, P. 9-12.

9. Gry`shhenko, A. P., Macz`ko, L. I., Plyushh, M. Ya. 2002. Suchasna ukrayins`ka literaturna mova [Modern Ukrainian literary language]. Ky`yiv. Vy`shha shkola, 439 p.

10. Tocz`ka, N. 1991. Dy`dakty`chny`j material z fonety`ky` [Didactic material on phonetics]. Ky`yiv. Rad. shkola, 144 p.

УДК [37-042.4:004:316.772.5]:373.5(045)

DOI:10.31339/2617-0833-2020-1(28)-121-124

\title{
THE USING OF INFORMATION AND COMMUNICATION TECHNOLOGIES IN
} SECONDARY SCHOOL

Plisko Yaroslav, Rozman Iryna

\section{ВИКОРИСТАННЯ ІНФОРМАЦІЙНО-КОМУНІКАЦІЙНИХ ТЕХНОЛОГІЙ У СЕРЕДНІЙ ШКОЛІ}

Пліско Я.В., Розман I.I.

The article deals with the problems of introduction of information and communication technologies in the educational process of secondary education institutions, defines the state of the studied subject and prospects of introduction of the latest educational technologies. The importance of introduction of educational innovative and information technologies is clarified.

Key words: newest technologies, secondary education, traditional education, teaching aids.

У статті розглянуто сутність та функціональність інформаційних та комунікаційних технологій, визначено стан досліджуваної тематики та перспективи запровадження новітніх освітніх технологій. З`ясовано значення запровадження освітніх інновачійних та інформачійних технологій.

Впровадження інформаційно-комунікачійних технологій у навчально-виховний прочес відбувається активно, впливає на формування розвиненої особистості, оскільки це створює 
можливості для самовдосконалення, підвищення інтелектуального розвитку, сприяє кращзому оволодінню підростаючого покоління знаннями та вміннями, розвиваючи творчий напрям пізнавальної діяльності, допомагає формувати відповідні особистісні якості.

Професійна діяльність викладачів у разі використання комп'ютерних технологій та засобів навчання забезпечує підвищення у школярів мотивачіі до навчання; реалізачію соціальних изілей, розвиток учнів; самостійної роботи з навчальним матеріалом.

Ключові слова: новітні технологї, середня освіта, традиційна освіта, засоби навчання.

Traditional views in education on the formation of students' knowledge, skills and skills no longer satisfy society. Today's society needs not just conscientious performers who have certain knowledge and skills, appropriate skills, but a person able to solve emergent problems. One of the problems in education is the need to respond quickly to changes in society. Thus, the concept of "traditional learning" and "innovative learning" appeared in education [1, p.170]. The main task of traditional education is to fulfill the norms of education.

Traditional education as a system of knowledge acquisition is lagging behind the real needs of society. Today, we need education that is constantly updated with knowledge, technology, learning tools, organizational and management approaches. Innovation is an innovation, an upgrade, a change, a new approach, the result of an innovation process. Although many researchers do not refer to "innovative" processes for the development, use and dissemination of educational innovations, limited to defining only activities to create a new, from a practical point of view, the concept of "educational innovation" must be considered systemic. Innovative processes in the field of education should be the processes of searching for innovative ideas, creation of innovative products in pedagogical science and in the education system, their perception by the socialpedagogical community [2, p.255]. Introduction of educational innovative and information technologies is one of the priority directions of the state policy on development of educational environment of Ukraine.

The essence of innovative education can be conveyed with the words: "not to catch up with the past, but to create the future" [3].

The development of forms of innovative education is part of the overall process of using information and communication technologies.

There are several statements regarding the definition of pedagogical innovation. Danylenko L. characterizes it as the newest pedagogical product - the result of the process of creation of a new one, which accordingly updates the pedagogical theory and practice, has a progressive beginning, which allows in the conditions of change to effectively solve problems in education. Dychkivska I. interprets "pedagogical innovation" as the content of planned changes in pedagogical activity that lead to the creation, development, use and dissemination of new approaches in pedagogical activity.

The analysis of international and domestic experience in the development of information and communication competence of participants in the educational process in secondary schools was studied by O. V. Ovcharuk and N.V. Soroko.. They identify major obstacles for educational institutions and teachers in creating a computer-based learning environment. The urgency of the question on the formation, development and evaluation of the IC-competence of participants in the educational process [4, p.55-56] is substantiated. V. V. Loboda considers the problem of informatization of education, introduction of information and communication technologies in the educational process and modernization of teaching of students by modern means of computeroriented educational environment. The teacher reveals the psychological aspect of the use of information technologies in education, as well as examines the place of ICT in the content of school education, their impact on the educational process in general, notes a systematic approach to integrate information and communication technologies in the educational process in order to improve the effectiveness of learning subjects [5] .

Any information process requires the teacher to possess information resources and 
communication technologies. To properly own the latest technologies, you need to build the right system for their use.

Innovative education aimed at the use of information and communication technologies is a model of education that requires maximum development of creative abilities and creation of strong motivation for self-development in teachers and students.

Introduction in the educational process of information technologies allows to implement the principles of differentiated approach to learning, to use distance learning. Possession of information technologies is along with such qualities of the student as ability to read and write. According to V. Bykov, in educational activities in educational institutions the problems of informatization should be given priority [6].

The development of the information society involves the use of information and communication technologies in education. Among the main factors in this process are:

- The introduction of information and communication technologies into education accelerates and improves the process of transferring knowledge and experience from generation to generation;

- New technologies, enhancing the quality of learning, enable the learner to adapt more quickly to the environment, to changes in society;

- Active introduction of information and communication technologies into education is an important factor in creating an updated education system.

The introduction of information and communication technologies is aimed at the use by teachers of modern teaching methods, focused on the activation of cognitive activity of students, depends on the knowledge and skills of the teacher, who must be able not only to use technologies in the educational processes and to develop educational and methodical materials, to create favorable conditions for them. using.

The pedagogical employee must meet the criteria of the new information personality: to have information technologies, to apply them effectively in their professional activity.

The achievements of the last decade in the field of creation of new pedagogical technologies in education using the means of information and communication technologies will allow to predict the realization of new types of information interaction between students and teachers [7].

Thus, the process of using information and communication technologies in general secondary education institutions requires the hard work of all participants in the educational process. The development and implementation of innovations in education stimulate the development of new teaching methods that require teachers of creative development and professional improvement.

\section{References}

1. Liba, O.M., 2015. Zahal'ni zasady innovatsiynykh tekhnolohiy navchannya [General principles of innovative teaching technologies]. In: Actual problems of scientific and educational space in the conditions of deepening of European integration processes: International scientific-practical conference. Mukachevo, 14-15 May 2015. Mukachevo: RVV MSU.

2. Fenchak, L.M. and Prokop, M.V., 2015. Vykorystannya innovatsiynykh pedahohichnykh tekhnolohiy u systemi osvity [Using of innovative pedagogical technologies in the education system]. In: Topical problems of scientific and educational space in the conditions of deepening of European integration processes: International scientific-practical conference. Mukachevo, 14-15 May 2015. Mukachevo: RVV MSU.

3. Vashchuka, F.H. ed., 2011. Novitni tekhnolohiyi v orhanizatsiyi navchal'noho protsesu [The latest technologies in the organization of the educational process]. In: Integration into the European educational space: achievements, problems, prospects. Uzhgorod: ZakDU.

4. Ovcharuk, O.V. and Soroko, N.V., 2015. Ohlyad porivnyal'no-pedahohichnykh doslidzhen' u haluzi rozvytku informatsiyno-komunikatyvnoyi kompetentnosti v systemi osvity [Review of comparative-pedagogical researches in the field of development of information- 
communicative competence in the educational system]. Information technologies and teaching aids, 45, 1, pp. 55-56.

5. Loboda,V.V., 2012. Pidvyshchennya yakosti navchal'noho protsesu zasobamy IKT [Improving the quality of the educational process by means of ICT] [online]. Information technologies and teaching aids, 4(30). Available at: http://www.journal.iitta.gov.ua.

6. Bykov, V.Yu., 2010. Suchasni zavdannya informatyzatsiyi osvity [Modern tasks of informatization of education]. Information Technologies and Teaching Aids, 1(15).

7. Zastosuvannya IKT v osvitn'omu protsesi zakladu zahal'noyi seredn'oyi osvity [Application of ICT in the educational process of a general secondary education institution.]. [online] Available at: https://vseosvita.ua/library/zastosuvanna-ikt-v-osvitnomu-procesi-zakladuzagalnoi-serednoi-osviti-15747.html.

\section{УДК 378.14}

DOI:10.31339/2617-0833-2020-1(28)- 124-129

\section{ПІДГОТОВКА ВЧИТЕЛЯ ДО ФОРМУВАННЯ ПРАВОВИХ ЗНАНЬ УЧНІВ ПОЧАТКОВИХ КЛАСІВ ЗАСОБАМИ ІННОВАЦІЙНО-ТВОРЧОЇ ДІЯЛЬНОСТІ} Попадич О. О.

\section{TEACHER TRAINING IN FORMATION OF PRIMARY SCHOOL STUDENTS' LEGAL KNOWLEDGE BY MEANS OF INNOVATIVE AND CREATIVE ACTIVITY}

Popadych Olena

Провідною ідеєю підготовки вчителя до формування правових знань учнів має бути спрямування на гуманістичні цінності, щз передбачає послуговування креативними методами та переходом педагога до інновачійної практики. Визначено найтиповіші ознаки готовності педагогів до втілення зазначених педагогічних вимог. Обтрунтовано вимоги щодо готовності вчителя початкової школи до формуванні правових знань учнів.

Ключові слова: початкова школа, вчитель, правові знання, креативність, інноватика

The main idea of teacher training in the formation of primary school students' legal knowledge should be focused on humanistic values, which involves the use of creative methods and the transition of the teacher to innovative practice. The most common features of the teacher' readiness to realize these pedagogical requirements have been defined, including the ability to recognize the student's free and personal will regarding the concept of the world; the ability to evaluate certain own actions as seen by the students, the ability and desire to pay attention to the views of the student, to understand his/her vision of the content and consequences of the proposed pedagogical ideas; a clear conviction that the teacher and student are possible equal partners in the educational process; ability to take into account the subjective experience of all students in the learning process, etc. It has been substantiated that the primary school teacher's readiness for the formation of students' legal knowledge includes the following issues: studying the personal students characteristics; analysis of legal knowledge specifics regarding the age abilities of primary school students; identifying the most effective sources of experience for students with different personal potential; the teacher's ability to diagnose the level of students' legal readiness; finding means of optimizing the students' legal knowledge formation; differentiation of the goals of legal training for students with different opportunities, in particular with regard to inclusive education opportunities; designing for a particular student the ability to independently expand and supplement legal knowledge; pedagogical support of students' positive aspirations; purposeful formation of students' ideas about legal values, as well as enhancing the methodological component of professional activity. 